DAVOR DŽALTO

University in Belgrade, Institute for Philosophy and Social Theory, Belgrade

DOI 10.5937/kultura1442174D

UDK 791.32:27-183

791.221.4(73)"2001"

kratko ili prethodno saopštenje

\title{
BREAKING FREE
}

WTHHOLLWWOOD

BLOCKBUSTERS

\begin{abstract}
The author explores freedom and love in Baz Luhrmann's movie "Moulin Rouge"! The author makes parallels between the way in which freedom and love, as basic human capacities, are addressed within the aesthetic framework of the movie, and the role that these capacities play in the Christian (especially Orthodox Christian) anthropology and ontology.
\end{abstract}

Key words: freedom, love, Moulin Rouge, theater, tragedy

2001 was a very productive year for the film industry. Among many movies released in that year, I want to focus on one that I consider an extraordinary achievement. It is a Baz Luhrmann's film Moulin Rouge, a film that manifests itself as a very rich source for reflection on some of the very basic ontoanthropological issues.

My claim is that Moulin Rouge is primarily a movie about freedom and love. These two themes make the movie very interesting from a theological perspective, since it can be claimed that freedom and love are central concepts in Christian theology in general, and in the Orthodox Christian theology in particular. It will analyze how freedom and love are depicted in this movie, and how we can reflect upon them from a theological perspective.

That said, the intention is not to argue that Moulin Rouge is about Christian anthropological concepts or that it is a movie made with intent to address particular theological issues. All I 


\section{DAVOR DŽALTO}

am saying is that the topics this movie explores, and the way these topics are approached, make it possible to relate them to an Orthodox Christian understanding of freedom and love as basic human capacities.

Moulin Rouge begins as a story about a young poet, Christian (Ewan McGregor), who comes to Paris. He clearly explains his intentions at the very beginning:

"I had come to live a penniless existence. I had come to write about the truth, beauty, freedom and that which I believed in above all things: love."

He lives in Montmartre where he meets a group of artists lead by Toulouse-Lautrec. They want christian to help them finish preparations for a show "Spectacular Spectacular" that they intend to present to Mr. Zidler, the owner of the Moulin Rouge. They hope to convince Zidler to stage the performance at the Moulin Rouge. The Moulin Rouge is, from this historical distance, not only a famous cabaret/bordello, but a place that signifies Bohemian life with all its virtues and vices, glories and miseries. The Moulin Rouge had obtained a cult status in the history of Paris and in the history of avant-garde art. It was already a place of creative and erotic exaltations, as well as a place of suffering.

Toulouse has a plan to dress Christian in a suit and introduce him as a famous English writer to the Moulin Rouge's star, the courtesan Satine. Once Satine hears his poetry, she will convince Zidler to let Christian write the play. From the moment that Christian meets Satine, he falls in love with her. Satine mistakes Christian for a Duke she was supposed to meet, and realizes the mistake just before the Duke himself arrives at her chamber. Right there, in Satine's room, Toulouse-Lautrec and the rest of the group, together with Zidler, stage a small performance for the Duke, trying to convince him to sponsor the production of the show. The story, as they present it to the Duke, "is about love." In that story, an evil maharajah invades a kingdom. To save the kingdom, a courtesan - the most beautiful courtesan in the whole world - has to seduce the maharajah. However, on the night of seduction she mistakes a penniless sitar player, who is dressed as a maharajah, for maharajah himself, and falls in love with him.

The motifs of seduction, mistaken identities and falling in love become crucial here. Christian quickly transforms the "real" course of events into a story, which should, in return, impact the reality; in reality, the story (between him and Satine) has just 
started, and the story for the play has to be told in such a manner, which would convince the Duke to invest.

Already here the main structure of the play is unveiled: stories are being told within the stories themselves. The "reality" and the "play" intertwine, which often makes it very difficult to differentiate reality from the play and the play from reality. Mistaken identities can be interpreted as playing a false role (Christian playing the Duke, the sitar player playing the maharajah), which makes it possible for a "real" identity to appear. In other words, only by playing the false role can the human being come to a situation in which his/her real identity is revealed. That is the moment of falling in love, in which the true identity of the lover is revealed. From the point of view of the Orthodox theology, this is a precise description of how human real, personal identities emerge. The transformation from a being who wears a mask - a specific role played in biological or social life - one needs to "love, and be loved in return" (the words from the very beginning of the movie). A relation of love is what constitutes the human being, and what makes it possible to really "know" someone.

The Duke likes the idea but, at the end of the improvised performance, he asks prophetically:

"And in the end, should someone die?"

He decides to support the production of the show and, moreover, he offers Zidler money to invest in the Moulin Rouge in order to transform it into a "real theater". In return he asks for Satine to be his exclusive concubine. However, the course of events begins to resemble the course of the story; the image of "real life" starts imitating the story (art) and not vice versa.

Satine falls in love with Christian and during rehearsals for their show they keep seeing each other secretly, hiding from Zidler and the Duke. Spending the night with the Duke is constantly postponed. The Duke finally warns Zidler that he might stop financing the show if Satine does not visit him. Horrified with the idea that the Duke might stop financing the project, Zidler insists that Satine must meet the Duke, and arranges a meeting. However, that very evening, Satine faints. The doctor discovers that she is suffering from tuberculosis and will not live much longer. This moment signifies the turning point, when, following the classical tragic narrative, the pleasures and enjoyment, based on the sin that has been committed, must turn into their opposite, into a suffering as a compensation for the $\sin$. The $\sin$ in this case is Satine's and Christian's secret love, which goes against the "rules" and expectations of the micro-cosmos in which their life- and art-story takes place. Instead of making the rational 


\section{DAVOR DŽALTO}

choice - to choose the Duke, who can bring her success and happiness and enable her to become "a real actress" - Satine chose unwisely - the penniless sitar player, Christian. This choice defies the firm and rational structure of the (micro) cosmos, and therefore it must be punished for that.

The Duke eventually discovers Satine's affair with Christian, and thus also realizes the parallel between the play he is financing and the "real" narrative going on between Satine and Christian, and the image of himself as the "evil maharajah." Being unable to make Satine love him, the Duke demands that Zidler and the group rewrite the script. The Duke wants the story end "his way," with the evil maharajah and concubine ending up together. In other words, being unable to change the situation in "reality," the Duke decides to change the play.

To preserve the original ending and save the play from the last minute changes, Satine offers the Duke to dine with him and spend the night together. However, on her way to the Duke's chamber, Satine realizes she cannot sleep with the Duke or maintain the pretense anymore. When the Duke tries to rape her, she is rescued by one of the cabaret dancers. She reunites with Christian, with whom she makes plans to run away from the Moulin Rouge, the Duke, and her past life.

This can be interpreted as her second sin which seals her destiny. She rebels against the Duke, who in Zidler's words is "a powerful man," a man who can decide, in a divine manner, about life and death.

While Satine is preparing to leave, Zidler comes to her room trying to stop her he tells her that the Duke plans to kill Christian. The only solution is to accept the merciless destiny; she must stay and spend the night with the Duke. Satine makes a final attempt to escape the inevitable course of events. She makes an attempt to break free:

"I don't need you anymore! All my life you made me believe I was only worth what someone would pay for me!

But Christian loves me. He loves me Harold. He loves me.

And that is worth everything. We are going away from you, away from the Duke, away from the Moulin Rouge!"

This is the culmination of Satine's rebellion against the (micro) cosmos and the culmination of her attempt to be free, to live an authentic existence. The foundation of this new existence is love. It is important to note that she repeats three times that Christian loves her. In the middle of this tragic narrative, Satine is using another ancient literary form, typical, but not exclusive, of the Bible and the Judeo-Christian tradition. It is the repetition of a 
word or a phrase three times, which is a symbol of endlessness and eternity. It is also a way to express the absoluteness, a way to confirm and seal something forever. In this case it is both their love and their personal identities that have been (newly) born.

At that moment, Zidler pronounces the verdict. He tells Satine the truth about her health:

"You are dying, Satine."

He convinces her that she must see the Duke in order to save the show, but also to save her lover, Christian. She must make Christian believe that she doesn't love him, which is the only way to prevent him from fighting for her and from trying to rescue her. It is also the only way to save Christian from the Duke who wants to kill him. Zidler's advice is:

"Send Christian away. Only you can save him. (...) Make him believe you don't love him. Hurt him. Hurt him to save him."

At this point, when the verdict has been announced, Zidler reveals the inescapable faith, the merciless, impersonal laws of destiny that seem to govern both human lives and human artistic production:

"The show must go on, Satine. We're creatures of the underworld. We can't afford to love."

Zidler then leaves her room. As he passes three seamstresses sitting on the staircase, he sings:

"Another hero, another mindless crime, behind the curtain, in the pantomime. On and on. Does anybody know what we are living for?"

The motif of three seamstresses reminds us of the Moirai, or Parcae, the goddesses of faith. In ancient Greek mythology, Clotho spins the thread of life from her distaff onto her spindle (birth), Lachesis measures the thread of life, while Atropos cuts the thread of life (death). This signifies the moment when Satine accepts the inevitability of her destiny, both as a person, and as a character in the play. She becomes an actress again, to perform a new role in the real life, to make Christian believe she does not love him anymore. Satine goes to Christian and tells him that they can no longer see each other, as she will be staying with the Duke.

On the first night of the show, Christian sneaks into the Moulin Rouge, to pay Satine as a whore, just as the Duke was ready to pay for her love. While demanding to hear from Satine that she does not love him, they find themselves in the middle of 
the play, right on the stage. After the initial confusion, Zidler, who plays the role of the evil maharajah, continues with his role and convinces the audience that Christian is the disguised sitar player. When Christian accepts what seems to be the inevitable, that the show will end the Duke's way, he steps down from the stage and walks toward the exit. Toulouse realizes what is going on, and shouts one of Christian's line:

"The greatest thing you'll ever learn is just to love and be loved in return."

Satine starts singing the song Christian wrote to express their love, which makes Christian realize that she is still in love with him. He returns and they reunite again, in the middle of the stage, singing their song. After the curtain closes, Satine and Christian affirm their love to each other, just before she dies. As the audience frenetically applaude, expressing a huge satisfaction with such a spectacular performance, Satine lies dead in the middle of her (micro)cosmos she tried to escape, in order to find a "real" life and become a "real" actress.

The whole movie, with its scenography, music, dance, photography, is itself "a spectacular spectacle." The combination of different artistic media, and the elimination of the border between a theatrical context and ordinary life, results in the Moulin Rouge being envisioned as a postmodern version of the Gesamtkunstwerk. The very structure of the movie is a postmodern collage, combining different styles, making it reminiscent to different historical periods and motifs.

This structure allows art and life to intertwine in such a way that a story from the artistic context (theater) affects things in the "real" life, and vice versa. The idea that art can become the means of contextualizing life, a place where life is better understood, or a place where life actually takes place has a long history. It can be found in ancient narratives, in Scheherazade and One Thousand and One Nights, or in modern stories such as Ivo Andrić's novel Aska and the Wolf. The artistic context or artistic performance stands in all of these examples for a space in which the main character is on a quest for freedom.

The topic of freedom, and the human attempt to overcome the boundaries of destiny and various sorts of necessities in the context of theater, is what connects the Moulin Rouge with the ancient tragic narratives in the most direct way, but also with the Christian understanding of freedom as the foundation of human (true) existence. In fact, Moulin Rouge can be understood as a typical postmodern story that repeats the structure of an ancient tragedy. The main character is, from the very beginning, sentenced to die. However, what constitutes the ancient tragedy 
is not only the inevitability of death, but also the inevitability of destiny which the main character faces in his or her attempt to become free. This motif is precisely what makes the ancient tragic narratives proto-Christian. As John Zizioulas pointed out in his book Being as Communion, ${ }^{1}$ it is through the context of ancient tragedies that we find a very clear idea of the human personal identity, which is affirmed through the tragic course of events. Human personal identity is born out of the human attempt to overcome the necessity of faith, to rebel against the everlasting laws and to exist in a free way. The tragic figures face the necessary punishment for the fact that they dared to confront the everlasting laws of cosmos (order), and to attempt to break them. However, even as they face death or endless suffering, it is precisely in this manifestation of their freedom against destiny that they appear as persons. However, what gives Moulin Rouge a distinct quality (from the point of view of Christian anthropology) is love which transcends all the boundaries of the world in which the characters are situated. For Christians, love, together with freedom, is the only way in which the uniqueness of human being can be established and sustained. In Moulin Rouge, love is a means to overcome the state of necessity: the physical, social and existential traps in which human beings find themselves. Christian's love for Satine, and her love for him, becomes something, in Satine's words, "that is worth everything." In spite of her inability to escape the tragedy that somehow comes from within herself (tuberculosis), Satine is transformed into a unique person, someone who is not just a courtesan anymore, someone who has discovered the meaning of life. And that love, which gives the life a meaning, will last forever.

In considering Christian's original intention when he arrived in Paris, to "write about the truth, beauty, freedom and that which I believed in above all things: love," we find another motif which is significant from the point of view of Christian ontology. Truth, freedom and love (together with beauty) are parts of the same equation. For Christian theology, these categories are inseparable, since the "Truth" can only manifest itself, and can only become intelligible, through love. To love means to take part in making the truth present, and to participate in it. There cannot be truth outside the love relationship, since the very relationship of love constitutes the personal identity of those who love and are being loved. Personal identity is the primary ontological reality for Christians. Being a person is the revelation of truth, the revelation of the only true mode of existence - existence

1 Zizioulas, J. (1985) Being as Communion, Crestwood, NY: St. Vladimir's Seminary Press. 


\title{
DAVOR DŽALTO
}

in a communion. Thus the first and the final messages of the movie, its Alpha and Omega, are expressed in a sentence which summarizes not only the story of the Moulin Rouge but of the entire Christian teaching:

"The greatest thing you will ever learn is just to love, and be loved in return."

\section{BIBLIOGRAPHY:}

French, P. (September 9, 2001) Moulin Rouge, The Guardian. Available at: http://www.theguardian.com/film/2001/sep/09/ philipfrench1 (January 10, 2014)

Mitchell, E. (May 18, 2001) 'Moulin Rouge': An Eyeful, an Earful, Anachronism, The New York Times. Available at: http://www.nytimes. com/2001/05/18/arts/18ROUG.html (January 10, 2014)

Krenn, S. (2012) Postmodern and Oriental Elements in Moulin Rouge! Film Analysis. Hamburg: Diplomica Verlag.

Zizioulas, J. (1985) Being as Communion, Crestwood, NY: St. Vladimir's Seminary Press.

\author{
Давор Џалто \\ Универзитет у Београду, Институт за филозофију и друштвену теорију, \\ Београд
}

\section{ХОЛИВУДСКИ БЛОКБАСТЕРИ НА ПРЕКРЕТНИЦИ}

\section{Сажетак}

У овом раду аутор се бави филмом База Лурмана Мулен Руж (2001) и начином на који је проблем слободе и љубави постављен у овом филму. Аутор успоставља паралеле између начина на који су слобода и љубав интерпретирани у оквиру естетске структуре филма, и улогом коју ови појмови играју у хришћанској, нарочито православној антропологији и онтологији.

Кључне речи: слобода, љубав, Мулен Руж, позориште, трагедија 